\title{
Development and survival of pig blastocysts after oestrogen administration on Day 9 or Days 9 and 10 of pregnancy*
}

\author{
G. L. Morgan $\dagger$, R. D. Geisert $\ddagger$ M. T. Zavy§ and A. T. Fazleabas $\uparrow$ \\ $\dagger$ Department of Veterinary Medicine and Surgery and $\ddagger$ Animal Science Department, Oklahoma \\ State University, Stillwater, OK 77078; §US Department of Agriculture, ARS, El Reno, OK 73036; \\ and Department of Obstetrics and Gynaecology, University of Illinois, Chicago, IL 60612, U.S.A.
}

\begin{abstract}
Summary. In Exp. 1, administration of $5 \mathrm{mg}$ oestradiol valerate i.m. to pregnant gilts on Days 9 or 9 and 10 advanced the uterine secretion of calcium, protein, and acid phosphatase as demonstrated by levels recovered in the uterine flushings of females unilaterally hysterectomized on Day 11. Upon removal of the remaining uterine horn on Day 12, protein and acid phosphatase increased while $\mathrm{Ca}^{2+}$ decreased in oestradioltreated gilts as did PGF. In contrast, a 4-fold increase in recoverable $\mathrm{Ca}^{2+}$ occurred from Days 11 to 12 in control gilts. Recoverable oestradiol-17 $\beta$ was increased in all 3 groups on Day 12 and plasmin inhibitor concentration increased in oestradiol-treated gilts. Two-dimensional PAGE demonstrated the appearance of a group of very acidic polypeptides in oestradiol-treated gilts. Blastocysts recovered from the second uterine horn had undergone elongation to the filamentous morphology in all 3 groups.

In Exp. 2, oestradiol valerate was administered to pregnant gilts on Day 9 or Days 9 and 10 followed by total hysterectomy on Day 16 . No differences in recoverable $\mathrm{Ca}^{2+}$ or protein were found, but acid phosphatase was decreased by $75 \%$ after oestradiol treatment. Recoverable oestradiol was decreased in oestradiol-treated gilts while PGF and plasmin inhibitor concentrations were unaffected. Compared with the control gilts, blastocysts recovered from oestradiol-treated gilts were fragmented and degenerating on Day 16. PAGE demonstrated greatly intensified staining of the group of acidic polypeptides in oestradiol-treated gilts.

These results indicate that oestradiol treatment on Day 9 of pregnancy advances uterine secretory response, but that blastocyst elongation can occur in this uterine environment and in the presence of declining intraluminal $\mathrm{Ca}^{2+}$ levels. However, the blastocysts fail to survive to Day 16, presumably due to failure of attachment because of an alteration in the uterine secretory environment and/or changes in uterine surface proteins.
\end{abstract}

\section{Introduction}

Utilizing embryo transfer, several studies have clearly demonstrated the necessity for close synchrony between stage of embryonic development and uterine environment (Moore \& Shelton, 1964; Wilmut \& Sales, 1981; Polge, 1982). Coincidental to the onset of rapid trophoblastic elongation which results in a marked alteration of the biochemical composition of the intrauterine environment on Day 12 of pregnancy, pig blastocysts begin to synthesize and secrete oestrogen (Perry et al., 1973, 1976; Geisert et al., 1982a). Pope \& First (1985) reported that gilts injected with

\footnotetext{
*Reprint requests to Professor R. D. Geisert.
} 
oestradiol valerate on Days 9 and 10 of pregnancy failed to remain pregnant by Day 30 . However, if oestrogen was administered on Days 12 and 13 of pregnancy, i.e. presumably after blastocysts have elongated and initiated their own synthesis and secretion of oestrogen, pregnancy was maintained.

Pig blastocysts begin to secrete large quantities of oestrogen and elongate after attaining a spherical diameter of $10 \mathrm{~mm}$ on about Day 11.5 of gestation (Gadsby et al., 1980; Geisert et al., 1982a; Fischer et al., 1985). The uterine secretory response induced by blastocyst oestrogen release can also be mimicked by exogenous oestrogen administration (Geisert et al., 1982c). Therefore, the uterine secretory response normally induced by blastocyst oestrogen release could possibly be altered by administering exogenous oestrogen on Day 9 or Days 9 and 10 (Geisert et al., 1987).

The present study was designed to establish the period in which early embryonic mortality occurs after gilts are treated with exogenous oestrogen before Day 11 of pregnancy, and to determine possible causes of early mortality when blastocysts are exposed to a uterine environment which is advanced relative to their normal development.

\section{Materials and Methods}

Animals. Sexually mature crossbred gilts of similar age (7-8 months), weight $(100-130 \mathrm{~kg})$ and having exhibited at least two oestrous cycles of normal duration (18-22 days) were used. Gilts were observed for oestrous behaviour twice daily $(08: 00$ to $18: 00 \mathrm{~h})$ in the presence of intact boars with the initial day of oestrus designated Day 0 . Gilts were mated to fertile boars at the onset of oestrus and $12 \mathrm{~h}$ and $24 \mathrm{~h}$ later.

Experiment 1. Gilts were randomly assigned $(\mathrm{N}=4)$ to receive one of the following treatments: control, intramuscular injection ( $4 \mathrm{ml}$ ) of vehicle (sesame oil) on Days 9 and 10 of pregnancy (Group C); a single intramuscular injection of $5 \mathrm{mg}$ oestradiol valerate (R. J. Legere \& Co., Scottsdale, AZ, U.S.A.) on Day 9 of pregnancy (Group E9); an intramuscular injection of $5 \mathrm{mg}$ oestradiol valerate on Days 9 and 10 of pregnancy (Group E9 +10 ).

On Day 11 of pregnancy, gilts were unilaterally hysterectomized after induction of anaesthesia with a $5 \%$ solution of thiopentone sodium (Abbott Laboratories, Chicago, IL, U.S.A.) and maintenance on a closed circuit system of halothane (2-5\% Fluothane: Aveco Co., Fort Dodge, IA, U.S.A.) and oxygen $(1 \cdot 0 \mathrm{l} / \mathrm{min})$.

After exposure by midline laparotomy, one uterine horn and the ipsilateral ovary were removed and placed on ice. The incision site was then closed in a routine manner. The uterine horn was trimmed free of mesometrium and flushed with $20 \mathrm{ml}$ sterile saline $(9 \mathrm{~g} \mathrm{NaCl} / \mathrm{l})$ to recover the uterine luminal contents. Uterine flushings were immediately examined for blastocysts whose number and size were recorded. Flushings were centrifuged at $12000 \mathrm{~g}$ for $20 \mathrm{~min}$ at

Table 1. Means for total calcium, protein and acid phosphatase activity in unilateral Day 11 and Day 12 uterine flushings from pregnant gilts treated with oestradiol valerate or vehicle on Day 9 or Days 9 and 10 of pregnancy

\begin{tabular}{|c|c|c|c|c|c|}
\hline \multirow[b]{2}{*}{ Group } & \multirow{2}{*}{$\begin{array}{c}\text { Day of } \\
\text { unilateral } \\
\text { hysterectomy }\end{array}$} & \multirow[b]{2}{*}{$\begin{array}{c}\text { Calcium } \\
\text { (mg) }\end{array}$} & \multirow[b]{2}{*}{$\begin{array}{l}\text { Protein* } \ddagger \\
\quad(\mathrm{mg})\end{array}$} & \multicolumn{2}{|c|}{ Acid phosphatase } \\
\hline & & & & $\begin{array}{c}\text { Activity } \dagger \\
(\mu \mathrm{mol} \mathrm{Pi} / \mathrm{min})\end{array}$ & $\begin{array}{c}\text { Specific activity* } \\
(\mu \mathrm{mol} \mathrm{P} / \mathrm{min} / \mathrm{mg} \text { protein })\end{array}$ \\
\hline $\mathrm{C}$ & $\begin{array}{l}11 \\
12\end{array}$ & $\begin{array}{l}0 \cdot 30 \\
1 \cdot 17\end{array}$ & $\begin{array}{l}25 \\
36\end{array}$ & $\begin{array}{l}20 \\
59\end{array}$ & $\begin{array}{l}0.82 \\
1.84\end{array}$ \\
\hline E9 & $\begin{array}{l}11 \\
12\end{array}$ & $\begin{array}{l}1 \cdot 10 \\
0.73\end{array}$ & $\begin{array}{l}46 \\
70\end{array}$ & $\begin{array}{l}104 \\
274\end{array}$ & $\begin{array}{l}2 \cdot 32 \\
4 \cdot 00\end{array}$ \\
\hline $\mathrm{E} 9+10$ & $\begin{array}{l}11 \\
12\end{array}$ & $\begin{array}{l}0.53 \S \\
0.16\end{array}$ & $\begin{array}{l}39 \\
81\end{array}$ & $\begin{array}{l}100 \\
178\end{array}$ & $\begin{array}{l}2 \cdot 10 \\
2 \cdot 31\end{array}$ \\
\hline Overall s.e.m. & & \pm 0.33 & \pm 7 & \pm 26 & \pm 0.44 \\
\hline
\end{tabular}

*Day effect $(P<0 \cdot 01)$.

Treatment $\times$ day interaction $(P<0.08)$.

Treatment effect $(P<0 \cdot 01)$.

§abnormally low levels were recovered in uterine flushings on Days $I 1$ and 12 from 2 gilts containing normal elongated blastocysts on Day 12. 
$4^{\circ} \mathrm{C}$ and the supernatant obtained was stored at $-20^{\circ} \mathrm{C}$ until analysed for calcium, protein (quantitative and qualitative), acid phosphatase activity, prostaglandin F, oestradiol-17 $\beta$, and plasmin inhibitor content.

Based on the size of blastocysts recovered from the first horn on Day 11, an estimation was made as to when blastocyst elongation would occur in the remaining horn as previously described by Geisert et al. (1982b). The second uterine horn was then removed (usually on Day 12) and flushed in the same manner as previously described.

Experiment 2. Twelve gilts were randomly assigned $(\mathrm{N}=4)$ to the 3 treatment groups as described for Exp. 1 . Total hysterectomy was performed on Day 16 with each uterine horn trimmed of mesometrium and flushed as in Exp. 1. Recovered blastocysts, if present, were evaluated for intactness (non-degenerating/degenerating). After centrifugation, uterine flushings were stored until analysed as in Exp. 1.

Analysis of uterine flushings. Detailed descriptions for the analysis of calcium, protein, acid phosphatase activity, plasmin inhibitors, oestradiol-17 $\beta$, and prostaglandin F (PGF) are given by Morgan et al. (1987). Intra- and interassay coefficients of variation for oestradiol- $17 \beta$ were $24.9 \%$ and $18.0 \%$, respectively, and sensitivity of the assay procedure was $2 \mathrm{pg} / \mathrm{ml}$. All samples analysed for PGF content were measured in a single assay which had an intraassay coefficient of variation of $2.9 \%$. Sensitivity of the assay with respect to the standard curve was $25 \mathrm{pg}$.

Two-dimensional polyacrylamide gel electrophoresis (PAGE) was performed ( $300 \mu \mathrm{g}$ protein loaded) for acidic and basic proteins as described by Morgan et al. (1987).

Statistical analysis. Data were analysed by least squares analysis of variance using the General Linear Models procedures of the Statistical Analysis System (Barr et al., 1979). The overall statistical model for analyses of uterine flushings in Exp. 1 included effects of treatment, Day of horn removal and treatment by Day interaction. Orthogonal contrasts for both experiments were made between Group C versus Groups E9 and E9 + 10, and Group E9 versus Group E9 + 10 .

\section{Results}

\section{Experiment 1}

The average diameter of spherical blastocysts recovered on Day 11 was $7 \mathrm{~mm}$ with a range of 2 to $11 \mathrm{~mm}$. Administration of oestradiol did not affect normal blastocyst development because gilts in Groups E9 and E9 + 10 contained filamentous blastocysts of normal appearance after removal of the second horn.

As shown in Table 1, a significant treatment by day interaction was detected for acid phosphatase activity $(P<0.08)$ while total uterine protein content was affected by treatment $(P<0.01)$ and day $(P<0.01)$. Day effects $(P<0.01)$ were detected for specific activity of acid phosphatase. Although non-significant, oestradiol valerate treatment on Day 9 and Days 9 and 10 stimulated an increase in uterine calcium on Day 11 followed by a decline on Day 12, whereas in vehicle-treated gilts the calcium levels increased 4-fold from Day 11 to Day 12. Although the calcium content in flushings recovered from two gilts in Group E9 + 10 on Day 11 and 12 was very low to undetectable, blastocyst elongation appeared normal. Oestradiol valerate treatment increased uterine protein content approximately 2 -fold $(P<0.01)$ from Day 11 to 12 but only a small increase occurred in the vehicle-treated gilts. Acid phosphatase activity was greater $(P<0 \cdot 10)$ on Days 11 and 12 in the uterine flushings of gilts in Groups E9 and E9 + 10 compared with controls in Group C.

A significant treatment by day interaction was detected for plasmin inhibitor $(P<0.04)$ with increased quantities recovered from uterine flushings in the second horn of gilts in Group E9 +10 (Table 2). This may reflect an increased stimulation of release due to oestradiol treatment or decreased binding of plasmin inhibitor to the blastocysts. Total recoverable oestradiol was significantly affected by Day $(P<0.01)$ with oestradiol content being greater in Day 12 uterine flushings $(4.0 \mathrm{ng})$, i.e. after blastocyst elongation, than in those on Day $11(0.9 \mathrm{ng})$.

Although non-significant, recoverable levels of PGF decreased from Day 11 to 12 in both oestrogen-treated groups in contrast to an increase in the controls. Whether this is an indication that blastocyst development and biochemical activity is being affected is not known.

Basha et al. (1980) have previously described acidic and basic polypeptides in pig uterine flushings after two-dimensional PAGE analysis. Profiles of acidic polypeptides present in Day 12 uterine flushing from gilts in Group $\mathrm{C}$ and oestradiol-treated gilts are illustrated in Figs 1(a) and 
Table 2. Means for total oestradiol, prostaglandin $\mathbf{F}$ and plasminogen inhibitor in unilateral Day 11 and Day 12 uterine flushings from pregnant gilts treated with oestradiol valerate or vehicle on Day 9 or Days 9 and 10 of pregnancy

\begin{tabular}{lcccc}
\hline Group & $\begin{array}{c}\text { Day of } \\
\text { unilateral } \\
\text { hysterectomy }\end{array}$ & $\begin{array}{c}\text { Oestradiol } \dagger \\
(\mathrm{pg})\end{array}$ & $\begin{array}{c}\text { Prostaglandin F } \\
(\mathrm{ng})\end{array}$ & $\begin{array}{c}\text { Plasmin } \\
\text { inhibitor* } \\
(\mathrm{IU})\end{array}$ \\
\hline $\mathrm{C}$ & 11 & 867 & $8 \cdot 03$ & 35876 \\
& 12 & 2780 & $12 \cdot 81$ & 14474 \\
E9 & 11 & 915 & $15 \cdot 18$ & 23523 \\
& 12 & 5987 & $3 \cdot 77$ & 27079 \\
E9 +10 & 11 & 935 & 0.64 & 25001 \\
& 12 & 3139 & 0.49 & 54844 \\
Overall s.e.m. & & \pm 927 & \pm 6.37 & \pm 7760 \\
\hline
\end{tabular}

*Treatment by day interaction $(P<0.04)$.

†Day effect $(P<0.01)$.

1(b). Two endometrial proteins $\left(M_{\mathrm{r}} 18000 ; \mathrm{pI}=6 \cdot 6 \cdot 6 \cdot 3\right)$ appeared on Days 11 and 12 in all the gilts, but intensity of staining was noticeably increased in the oestradiol-treated gilts. Two additional acid polypeptides $\left(M_{\mathrm{r}} 22000\right.$ and $\left.40000 ; \mathrm{pI}=5.4\right)$ appeared in oestradiol-treated gilts on Day 12, but were absent in vehicle-treated gilts.

Basic polypeptides from uterine flushings which were detected by PAGE are similar to those identified by Basha et al. (1980). Uteroferrin $\left(M_{\mathrm{r}} 35000 ; \mathrm{pI}=9 \cdot 7\right)$ and two other basic endometrial proteins $\left(M_{\mathrm{r}} 50000-60000 ; \mathrm{pI}=9 \cdot 7\right)$ appeared on Day 12 (gels not presented). Although similar qualitative changes occurred in vehicle- and oestradiol-treated gilts between Days 11 and 12, the staining intensity of uteroferrin increased in earlier oestradiol-treated gilts. The increase in intensity on Day 11 would be consistent with a greater content of acid phosphatase activity since over $90 \%$ of acid phosphatase activity in the uterus is due to uteroferrin. Oestradiol valerate treatment did not appear to affect plasmin isoinhibitors.

\section{Experiment 2}

The proportions of gilts with degenerating embryos on Day 16 were $0 / 4,2 / 4$ and $4 / 4$ for Groups $\mathrm{C}, \mathrm{E} 9$, and $\mathrm{E} 9+10$, respectively. In comparison to the large mass of intact filamentous blastocysts present in uterine flushings of vehicle-treated gilts, conceptus tissues in oestrogen-treated gilts were fragmented and degenerate. Flushings from these gilts contained excessive amounts of cellular debris with only a few intact filamentous blastocysts present. Oestradiol valerate treatment did not affect total recoverable calcium or protein present in uterine flushings, but did decrease $(P<0.03)$ total recoverable acid phosphatase and specific acid phosphatase activity approximately $75 \%$ (Table 3).

Lower $(P<0.01)$ amounts of oestradiol were recovered from Day 16 uterine flushings of Groups E9 and E9 + 10, but PGF and plasmin inhibitor measurements were unaffected by oestradiol treatment (Table 4).

Although no quantitative differences were detected for total amount of recoverable protein, oestrogen administration stimulated specific quantitative changes in polypeptides present in uterine flushings on Day 16 (Figs $2 \& 3$ ) as determined by the staining intensity on two-dimensional PAGE gels. Oestradiol valerate administration altered the staining intensity of a number of acidic and basic polypeptides. One group of very acidic polypeptides $\left(M_{\mathrm{r}} 40000 ; \mathrm{pI}=5.4\right)$ was especially intensified in uterine flushings from oestradiol-treated gilts (Fig. 2b), whereas the same polypeptides were barely discernible in profiles of control gilts (Fig. 2a). 


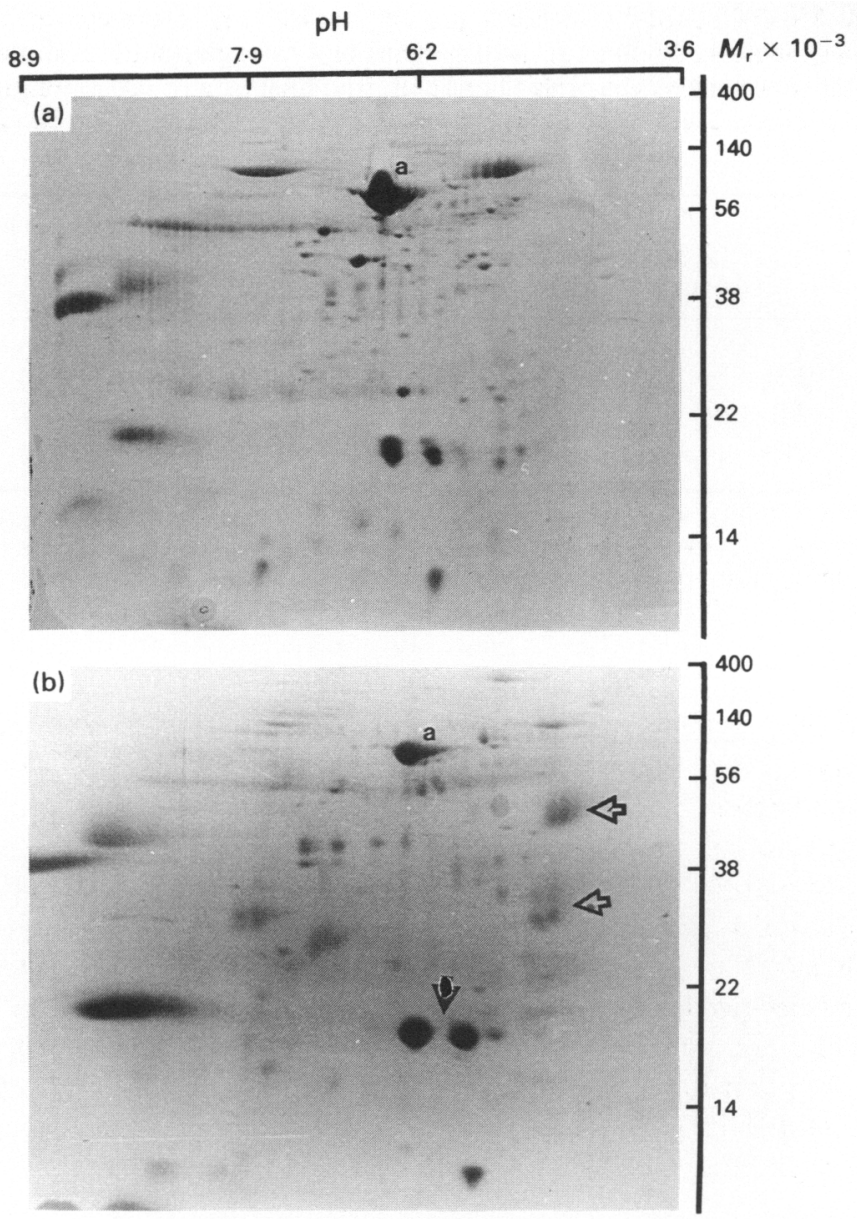

Fig. 1. Two-dimensional gel electrophoresis of acidic polypeptides in Day-12 uterine flushings from (a) a vehicle-treated gilt (Group C) and (b) a gilt treated with $5 \mathrm{mg}$ oestradiol valerate on Days 9 and 10 (Group E9 + 10). There is increased staining intensity of two progesteroneinduced polypeptides (solid arrowhead) in the flushing of the oestrogen-treated gilt and two polypeptides (open arrowheads) which are not present in the vehicle-treated gilt flushings. $\mathrm{a}=$ serum albumin.

Table 3. Means for total calcium, protein and acid phosphatase activity in Day 16 uterine flushings of pregnant gilts treated with oestradiol valerate or vehicle on Day 9 and Days 9 and 10 of pregnancy

\begin{tabular}{|c|c|c|c|c|}
\hline \multirow[b]{2}{*}{ Group } & \multirow[b]{2}{*}{$\begin{array}{l}\text { Calcium } \\
\text { (mg) }\end{array}$} & \multirow[b]{2}{*}{$\begin{array}{l}\text { Protein } \\
\text { (mg) }\end{array}$} & \multicolumn{2}{|c|}{ Acid phosphatase } \\
\hline & & & $\begin{array}{c}\text { Activity } \\
(\mu \mathrm{mol} \mathbf{P i} / \mathrm{min})\end{array}$ & $\begin{array}{c}\text { Specific activity } \\
(\mu \mathrm{mol} \mathrm{Pi} / \mathrm{min} / \mathrm{mg} \text { protein })\end{array}$ \\
\hline C & $0 \cdot 20$ & 172 & $1877^{\mathrm{a}}$ & $14 \cdot 60^{\mathrm{a}}$ \\
\hline E9 & 0.35 & 170 & $525^{b}$ & $3 \cdot 40^{\mathrm{b}}$ \\
\hline $\mathrm{E} 9+10$ & 0.29 & 160 & $250^{\mathrm{b}}$ & $3 \cdot 40^{\mathrm{b}}$ \\
\hline Overall s.e.m. & $\pm 0 \cdot 12$ & \pm 29 & \pm 265 & $\pm 3 \cdot 60$ \\
\hline
\end{tabular}

${ }^{\text {a,b }}$ Values with different superscripts are different $(P<0 \cdot 03)$. 
Table 4. Means for total oestradiol, prostaglandin $F$ and plasminogen inhibitor in Day-16 uterine flushings of pregnant gilts treated with oestradiol valerate or vehicle on Day 9 or Days 9 and 10 of pregnancy

\begin{tabular}{lccc}
\hline Group & $\begin{array}{c}\text { Oestradiol } \\
(\mathrm{pg})\end{array}$ & $\begin{array}{c}\text { Prostaglandin F } \\
(\mathrm{ng})\end{array}$ & $\begin{array}{c}\text { Plasmin } \\
\text { inhibitor } \\
(\mathrm{IU})\end{array}$ \\
\hline $\mathrm{C}$ & $1182^{\mathrm{a}}$ & 3.56 & 57823 \\
$\mathrm{E} 9$ & $584^{\mathrm{b}}$ & 4.80 & 86453 \\
$\mathrm{E} 9+10$ & $311^{\mathrm{b}}$ & 2.26 & 70812 \\
Overall s.e.m. & \pm 161 & \pm 1.23 & \pm 15683 \\
\hline
\end{tabular}

a.bValues with different superscripts are different $(P<0.01)$.

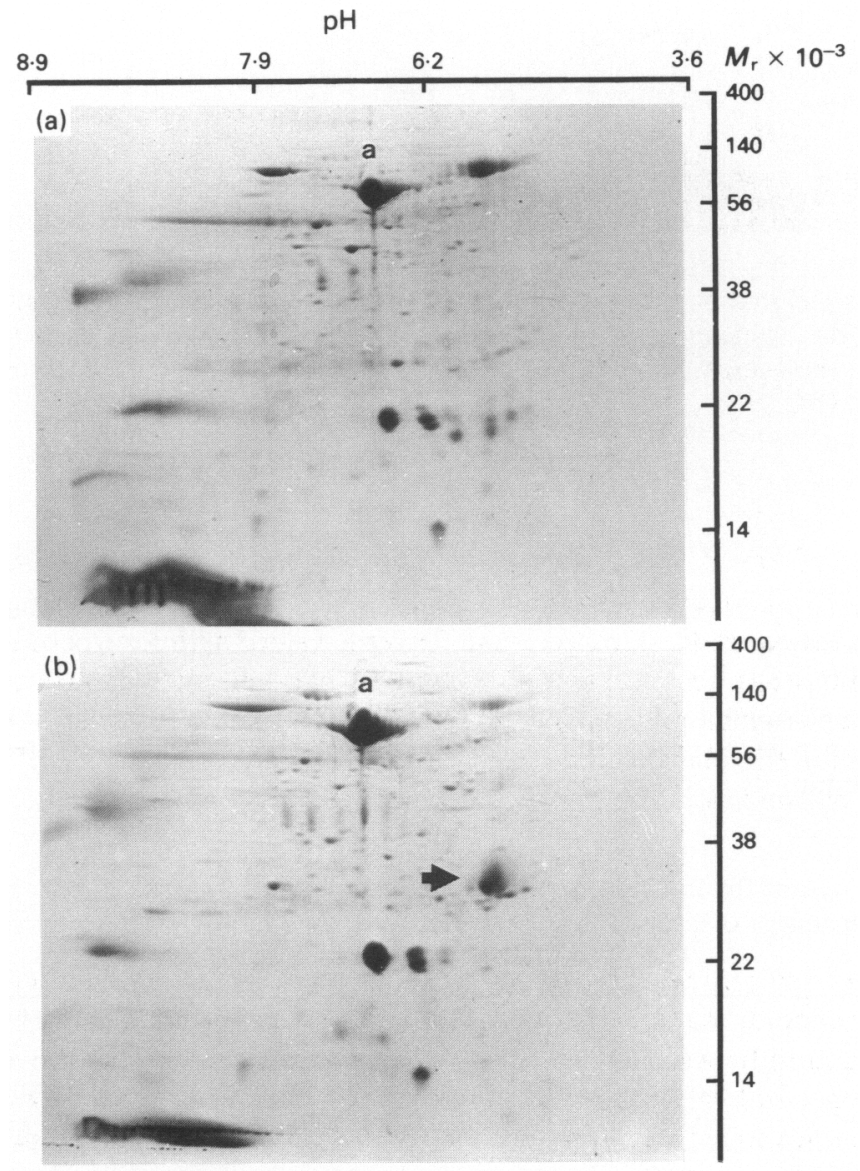

Fig. 2. Two-dimensional polyacrylamide gel electrophoresis of acidic proteins in Day-16 uterine flushings from (a) a vehicle-treated gilt (Group C) and (b) a gilt treated with oestradiol on Days 9 and 10 . Note the appearance of a group of very acidic polypeptides in (b) which is barely detectable in (a) (solid arrowhead), a = serum albumin. 


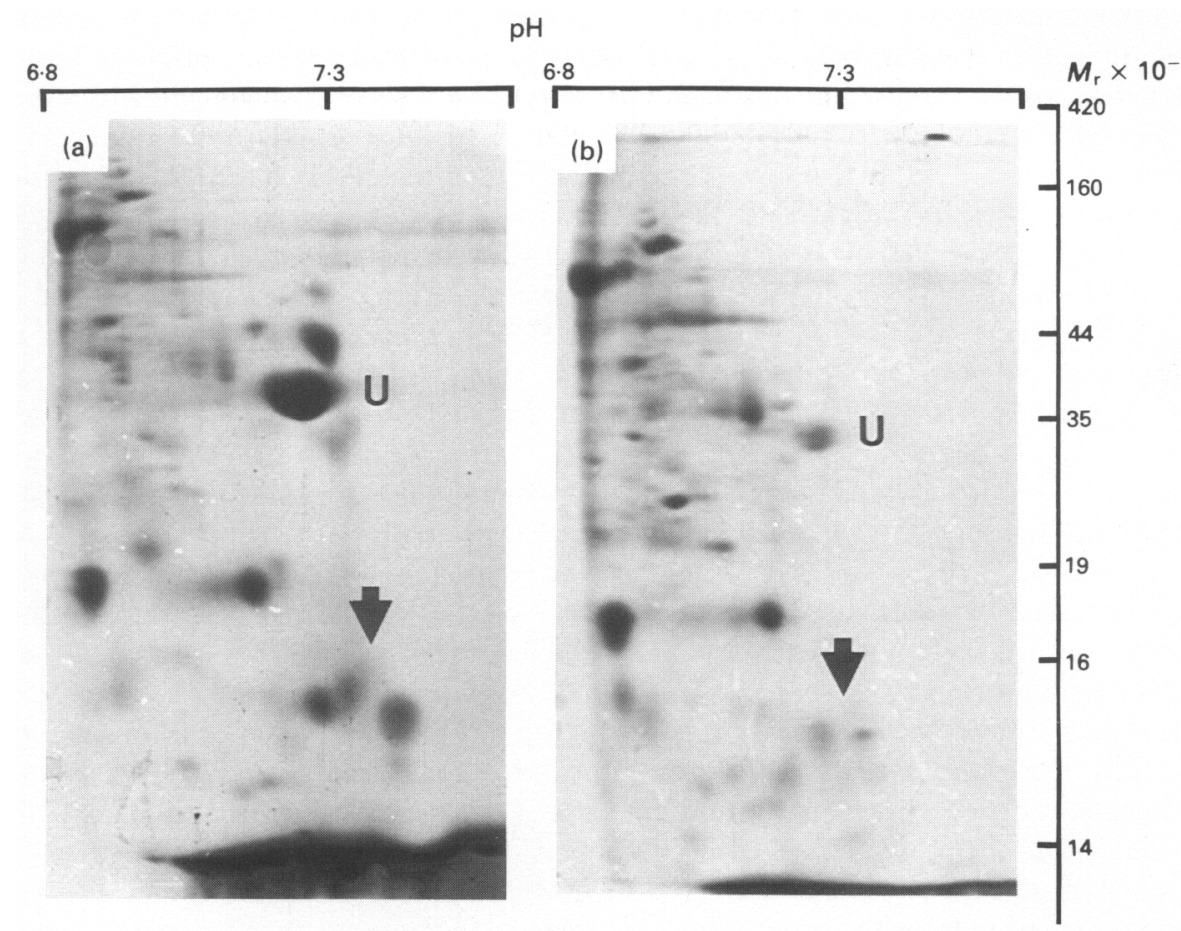

Fig. 3. Two-dimensional polyacrylamide gel electrophoresis of basic proteins in Day-16 uterine flushings from (a) a vehicle-treated gilt (Group C) and (b) a gilt treated with oestradiol on Days 9 and 10 . Note the decrease in staining intensity of uteroferrin (U) and plasmin isoinhibitors (solid arrow) in (b).

The appearance of uteroferrin $\left(M_{\mathrm{r}} 35000 ; \mathrm{pI}=9.7\right)$ and two other non-serum proteins $\left(M_{\mathrm{r}}\right.$ $50000-60000 ; \mathrm{pI}=9 \cdot 7$ ) located above uteroferrin (Figs 3a \& 3b) was greatly attentuated in Day-16 flushings from oestradiol-treated gilts. Decreased staining intensity of uteroferrin was also reflected by the lower acid phosphatase activity and specific acid phosphatase activity from uterine flushings of oestradiol-treated gilts (Table 3). Although oestradiol administration had no effect on the uterine content of the plasmin inhibitors (Table 4), staining intensity of the low molecular weight $\left(M_{\mathrm{r}} 14000\right)$ plasmin isoinhibitors (Fazleabas et al., 1983) appeared to be decreased (Fig. 3b).

\section{Discussion}

Geisert et al. (1982c) demonstrated that administration of oestrogen on Day 11 of the gilt oestrous cycle would induce endometrial secretion similar to that which occurs during blastocyst oestrogen synthesis and elongation between Days 11 and 12 of pregnancy. The uterine endometrium is not responsive to oestrogen until after the 10th day of the oestrous cycle (Geisert et al., 1987). However, uterine secretion was advanced on Days 11 and 12 by administration of oestrogen on Day 9.5 of the oestrous cycle. The alterations of calcium, acid phosphatase and protein in pregnant gilts after oestradiol administration in the present study are consistent with the changes reported in cyclic gilts (Geisert et al., 1987).

The failure of calcium to increase between Days 11 and 12 in oestradiol-treated gilts gives rise to doubts of the necessity of this response for blastocyst elongation to occur. Although the factors 
regulating elongation are unclear, it had been proposed that calcium may be involved, perhaps through activation of phospholipase $\mathrm{A}_{2}$ and subsequent methylation of membrane phospholipids (Geisert et al., 1986). The fact that elongated blastocysts were recovered from all gilts upon removal of the second horn on Day 12 indicated that the uterine advancement in protein and acid phosphatase secretion also did not interfere with the mechanism(s) regulating blastocyst elongation. However, gel electrophoresis did indicate qualitative as well as some selected quantitative changes in acidic polypeptide profiles of uterine flushings between vehicle and oestrogen treated gilts from Day 11 to 12. Similar changes in polypeptides were observed in cyclic gilts administered oestrogen on Day 9.5 (Geisert et al., 1987). Therefore, the polypeptides appear to be reflective of uterine secretion and not blastocyst degeneration. The role(s) of these polypeptides in blastocyst development are not known; however, they appear simultaneously with conceptus degeneration on Day 16.

It is apparent from Exp. 2 that advancing the uterine environment by administration of oestradiol on Day 9 or Days 9 and 10 created a uterine environment which was unfavourable to elongated blastocysts between Days 12 and 16. The fact that embryos were degenerated by Day 16 in the present study concurs with Pope \& First (1985) who reported that gilts treated with oestrogen in a similar fashion were not pregnant at Day 30. Geisert et al. (1987) indicated that treatment of gilts with oestradiol on Day $9 \cdot 5$ of the oestrous cycle extended the interoestrous interval to about 28 days. Loss of progesterone support is therefore not involved with the embryonic mortality observed in this study. Oestradiol has also been shown not to be directly embryocidal, since gilts will maintain pregnancy when oestrogen is administered after Day 11 (Pope \& First, 1985), and gilts treated with oestradiol in the present study had normal blastocysts present on Day 11.

After elongation, the next crucial step in establishing pregnancy is the attachment of the trophoblast membrane to the uterine luminal surface epithelium. In the pig, attachment occurs between Days 13 and 18 of pregnancy (King et al., 1982). Failure of attachment to occur must be considered as one possible explanation for the demise of embryos when given oestrogen on Day 9 and 10 .

The mechanism(s) involved in actual attachment of the blastocyst to the uterine epithelium are not well understood. However, attachment is probably mediated through specific ultrastructural and biochemical changes in the plasma membrane surfaces of the two opposing tissues, the trophoblast and uterine surface epithelium (Schlafke \& Enders, 1975). Anderson et al. (1986) have indicated that stage-specific alterations of protein and saccharide composition occur on the apical surface of the rabbit endometrium at the time of implantation. Other researchers have suggested that alteration of the glycoprotein coatings on both the trophoblast and epithelial cell plasma membrane may be responsible for the very close apposition necessary for interdigitation of microvilli (Enders \& Schlafke, 1974; Jenkinson \& Searle, 1977).

The close association of blastocyst degeneration with the appearance of an intensified group of acidic $(\mathrm{pI}=5.4)$ polypeptides $\left(M_{\mathrm{r}} 40000\right)$ after oestradiol treatment makes their involvement in conceptus development an interesting possibility. It is possible that these proteins are associated with the uterine epithelial surface and that oestradiol treatment before Day 10 causes their release, thus preventing normal blastocyst attachment.

Although the superficial type of placentation in the pig is markedly different from the invasive implantation in rodents, it is not unreasonable to speculate that ultrastructural and biochemical changes occur in the plasmalemma of the uterine surface epithelium in response to oestrogen for blastocyst attachment. If oestrogen advanced changes in the endometrial cell surface as well as uterine glandular secretion, e.g. uteroferrin, before the time of normal blastocyst attachment, the uterine environment may no longer be permissive to blastocyst attachment on Day 14 to 16 . The release of the plasmin inhibitors from the luminal surface epithelium may be indicative of such a change.

Blastocyst oestrogen appears to be the primary signal to the sow for pregnancy recognition (Heap et al., 1979; Bazer et al., 1982) and the sequencing of all subsequent events including 
attachment (Bazer \& Roberts, 1983). Premature exposure of the endometrium to oestrogen may alter this sequencing to such an extent that blastocyst attachment and survival is hindered.

Journal Article No. 5047 of Agricultural Experiment Station, Oklahoma State University, Stillwater. We thank Dr K. T. Kirton (The Upjohn Company) for the PGF antiserum; Dr G. D. Niswender (Department of Physiology and Biophysics, Colorado State University, Fort Collins, Colorado) for the 17 $\beta$-oestradiol-6 $\beta$-BSA antiserum; B. G. Biggers for technical assistance; and Eva Harrall and Kathy Frank for secretarial assistance. This material is based on work supported by the U.S. Department of Agriculture (Science and Education) under Agreement No. 86-CRCR-1-2105.

\section{References}

Anderson, T.L., Olson, G.E. \& Hoffman, C.H. (1986) Stage-specific alterations in the apical membrane glycoproteins of endometrial epithelial cells related to implantation in rabbits. Biol. Reprod. 34, 701-721.

Barr, A.J., Goodnight, J.H., Sall, J.P., Blair, W.H. \& Chilko, D.M. (1979) SAS User's Guide. SAS Institute Inc., Raleigh, N.C.

Basha, S.M.M., Bazer, F.W., Geisert, R.D. \& Roberts, R.M. (1980) Progesterone-induced uterine secretions in pigs. Recovery from pseudopregnant and unilaterally pregnant gilts. J. Anim. Sci. 50, 113-123.

Bazer, F.W. \& Roberts, R.M. (1983) Biochemical aspects of conceptus-endometrial interactions. J. exp. Zool. 228, 373-383.

Bazer, F.W., Geisert, R.D., Thatcher, W.W. \& Roberts, R.M. (1982) The establishment and maintenance of pregnancy. In Control of Pig Reproduction, pp. 227-252. Eds D. J. A. Cole \& G. R. Foxcroft. Butterworth Scientific, London.

Enders, A.C. \& Schlafke, S. (1974) Surface coats of the mouse blastocyst and uterus during the preimplantation period. Anat. Rec. 180, 31-46.

Fazleabas, A.T., Geisert, R.D., Bazer, F.W. \& Roberts, R.M. (1983) Relationship between release of plasminogen activator and estrogen by blastocysts and secretion of plasmin inhibitor by uterine endometrium in the pregnant pig. Biol. Reprod. 29, 225-238.

Fischer, H.E., Bazer, F.W. \& Fields, M.J. (1985) Steroid metabolism by endometrial and conceptus tissues during early pregnancy and pseudopregnancy in gilts. J. Reprod. Fert. 75, 69-78.

Gadsby, J.E., Heap, R.B. \& Burton, R.D. (1980) Oestrogen production by blastocyst and early embryonic tissue of various species. J. Reprod. Fert. 60, 409-417.

Geisert, R.D., Renegar, R.H., Thatcher, W.W., Roberts, R.M. \& Bazer, F.W. (1982a) Establishment of pregnancy in the pig. I. Interrelationships between preimplantation development of the pig blastocyst and uterine endometrial secretions. Biol. Reprod. 27, 925-939.

Geisert, R.D., Brookbank, J.W., Roberts, R.M. \& Bazer, F.W. (1982b) Establishment of pregnancy in the pig. II. Cellular remodelling of porcine blastocysts during elongation on day 12 of pregnancy. Biol. Reprod. 26, 94!-955.

Geisert, R.D., Thatcher, W.W., Roberts, R.M. \& Bazer, F.W. (1982c) Establishment of pregnancy in the pig. III. Endometrial secretory response to estradiol valerate administered on day 11 of the estrous cycle. Biol. Reprod. 27, 957-965.

Geisert, R.D., Rasby, R.J., Minton, J.E. \& Wettemann, R.P. (1986) Role of prostaglandins in development of porcine blastocysts. Prostaglandins 31, 191-204.

Geisert, R.D., Zavy, M.T., Wettemann, R.P. \& Biggers, B.G. (1987) Length of pseudopregnancy and pattern of uterine protein release as influenced by time and duration of oestrogen administration in the pig. $J$. Reprod. Fert. 79, 163-172.

Heap, R.B., Flint, A.P.F. \& Gadsby, J.E. (1979) Embryonic signals that establish pregnancy. Br. med. Bull. 34, 129-135.

Jenkinson, E.J. \& Searle, R.F. (1977) Cell surface changes on the mouse blastocyst at implantation. Expl Cell Res. 106, 386-390.

King, G.J., Atkinson, B.A. \& Robertson, H.A. (1982) Implantation and early placentation in domestic ungulates. J. Reprod. Fert., Suppl. 31, 17-30.

Moore, N.W. \& Shelton, J.N. (1964) Egg transfer in sheep. Effect of degree of synchronization between donor and recipient, age of egg and site of transfer on survival of transferred eggs. J. Reprod. Fert. 7, $145-152$.

Morgan, G.L., Geisert, R.D., Zavy, M.T., Shawley, R.V. \& Fazleabas, A.T. (1987) Development of pig blastocyst in an uterine environment advanced by exogenous oestrogen. J. Reprod. Fert. 80, 125-131.

Perry, J.S., Heap, R.B. \& Amoroso, E.C. (1973) Steroid hormone production by pig blastocysts. Nature, Lond. 245, $45-47$.

Perry, J.S., Heap, R.B., Burton, R.D. \& Gadsby, J.E. (1976) Endocrinology of the blastocyst and its role in the establishment of pregnancy. J. Reprod. Fert., Suppl. 25, 85-104.

Polge, C. (1982) Embryo transplantation and preservation. In Control of Pig Reproduction, pp. 277-291. Eds D. J. A. Cole \& G. R. Foxcroft. Butterworth Scientific, London.

Pope, W.F. \& First, N.L. (1985) Factors affecting the survival of pig embryos. Theriogenology 23, 91-105.

Schlafke, S. \& Enders, A.C. (1975) Cellular basis of interaction between trophoblast and uterus at implantation. Biol. Reprod. 12, 41-65.

Wilmut, I. \& Sales, D.I. (1981) Effect of an asynchronous environment on embryonic development in sheep. $J$. Reprod. Fert. 61, 179-184.

Received 1 August 1986 